\title{
Зниження енергетичних витрат при роботі холодильного обладнання під час зберігання соковитої рослинницької сировини
}

\author{
О. М. Томчик ${ }^{1 凶}$, М. Г. Хмельнюк ${ }^{2}$, М. І. Гоголь ${ }^{3}$ \\ Одеська національна академія харчових технологій, вул. Канатна, 112, м. Одеса, 65039, Україна \\ $\triangle$ e-mail: Fierysplash@ukr.net \\ ORCID: ${ }^{1}$ https://orcid.org/0000-0002-1132-2481 \\ 2 https://orcid.org/0000-0002-9310-1286 \\ 3 https://orcid.org/0000-0003-2679-653X
}

\begin{abstract}
Розглянуто спосіб зниження енергетичних витрат при холодильному зберіганні соковитої рослинної продукиї иляхом підвищення теплової інериійності та акумулюючої здатності охолоджуваного простору. Засобом підвищення теплової інериійності охолоджуваного простору є тара оригінальної конструкиї, виготовлена з полімерного матеріалу, з рідинними прошарками. Запропоновано використання упаковки, щзо являє собою ящик з кришкою з подвійними стінками. Між зовнішніми та внутрішніми стінками по всьому периметру упаковки передбачений зазор, заповнений рідиною з високою тепловою інериійністю. Проведено дослідження 3 визначення енергетичних витрат при зберіганні продукту. Результати досліджень при зберіганні плодів яблуні Гала (першого сорту) в упаковках різної конфігурації-експериментальних (з водяними прошарками 7 мм, 17 та 27 мм) і контрольних (без прошарків), показали, щуо при використанні упаковок з водяними прошарками витрати енергії на зберігання продукту знижуються на 17,5..21,1\%. Окрім того, дослідження показали, щзо в практично рівних умовах зберігання (середній температури в камері і амплітуди ї̈ коливань) при застосуванні упаковок з підвищеною теплової інериійністю (акумулюючою здатністю) з водяними прошарками, середній перепад температури плодів за 1 годину зменшився в 1,8...3,6 рази, амплітуда коливань температури плодів зменшилася в 4,9..10,1 рази, втрати маси продукту знизилися на 30,6...38,3\%, та дещо зменшилася амплітуда коливань повітря камери. Також для зберігання продукту запропоновано застосовувати стояковий піддон, щео містить вантажну платформу, опорний стояковий каркас та знімні елементи з полімерного матеріалу. При цьому знімні елементи установлені по периметру та зверху опорного каркасу. Кожен знімний елемент складається з чотирьох бокових, верхньої $і$ нижньої поверхонь, простір між якими заповнений рідиною $з$ високою тепловою інериійністю.
\end{abstract}

Ключові слова: Зберігання соковитої рослинної продукиї - Зниження витрат енергї - Коливання температури - Акумуляиія холоду - Упаковка з підвищеною тепловою інериійністю.

(C) The Author(s) 2018. This article is an open access publication

This work is licensed under the Creative Commons Attribution 4.0 International License (CC BY) http://creativecommons.org/licenses/by/4.0/

\section{1. Вступ}

Можливість забезпечення населення харчовими продуктами у необхідних межах є одним з головних показників рівня продовольчої безпеки країни. При цьому важливу роль у ії забезпеченні має стан структури холодильного господарства.

В кліматичних умовах України з високим потенціалом ï агропромислового комплексу, розвинуте промислове виробництво в стані не тільки забезпечити населення продовольством в необхідних обсягах, але й здійснювати експорт значної частини власної продовольчої сировини і готової продукції.

Результати численних обстежень холодильників різного призначення, виконані співробітниками Науково-дослідного сектору Інститута холода, кріотехнологій та екоенергетики ім. В. С. Мартиновського (IXКЕ) Одеської національної академії харчових технологій
(ОНАХТ), дозволили зробити висновок про невідповідність існуючої структури холодильного господарства України сучасним вимогам до зберігання поточних i резервних продовольчих запасів. Існуюча система зберігання включає холодильники, побудовані у різний час, за різними проектними рішеннями, з використанням різноманітних будівельних конструкцій та охолоджувальних систем. При цьому підтримання необхідних параметрів технологічного регламенту в таких об’єктах здійснюється в різних балансових умовах.

Дослідження американської організації USAID також свідчать про те, що стан холодильного господарства України незадовільний, наприклад, забезпеченість в холодильниках для зберігання різних видів рослинної продукції знаходиться в межах 2-22\% [1].

Недостатність загальної місткості національної системи зберігання продовольчих запасів і їі незадовільний стан призводять до збільшення експорту сирови- 
ни, або зменшенню обсягів їі виробництва, через неможливість забезпечення тривалого зберігання продукції 3 метою іiї поступової реалізації або обробки без застосування холодильних технологій. Це сприяє зростанню імпорту продукції сумнівної якості з зарубіжних країн, де вона не може бути вигідно реалізована, і $є$ загрозою продовольчої, економічної та національної безпеки України [1].

\section{2. Постановка задачі}

Розгляд результатів обстежень холодильних об'єктів дозволив зробити висновок про те, що на даний час встановилася практика експлуатації будівельно-ізоляційних конструкцій холодильників до повного зносу, без здійснення заходів до підтримання їх стану на нормативному рівні. При цьому погіршення теплозахисних та зростання інфільтраційних властивостей будівельно-ізоляційних конструкцій призводить до порушень параметрів технологічного регламенту, через які холодильне обладнання працює в непридатних умовах протягом більш тривалого часу щоденно, що значно скорочує термін його експлуатації. Знос холодильного обладнання, зазвичай, поступово компенсують заміною окремих елементів на нові та встановленням додаткового обладнання, а знос будівельно-ізоляційних конструкцій - ремонтними роботами. Але ці заходи, в більшості випадків, тільки продовжують строки експлуатації холодильників, не враховуючі взаємозв'язків між їх конструктивними особливостями i технологічними процесами, внаслідок чого їх моральний і фізичний знос продовжується, і призводить до значного зростання енергетичних витрат і втрат продукції вище діючого нормативного рівня [1].

Основною умовою забезпечення необхідної тривалості зберігання і збереження якості сировини і готової продукції є стабільне підтримання на необхідному рівні параметрів технологічного регламенту та їх ізотропності у вантажному просторі холодильних камер в період зберігання.

Стабільність підтримання параметрів технологічного регламенту значно залежить від показників тепло-

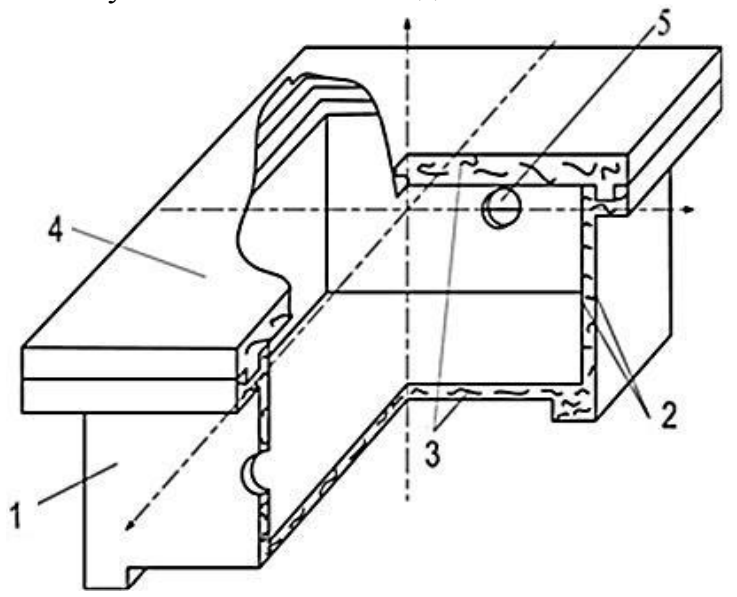

1 - упаковка; 2 - зовнішня і внутрішня стінки упаковки; 3 - рідина з високою тепловою інерцією; 4 - кришка упаковки; 5 - отвори для доступу повітря до продукту

Рисунок 1 - Упаковка з підвищеною тепловою інериійністю

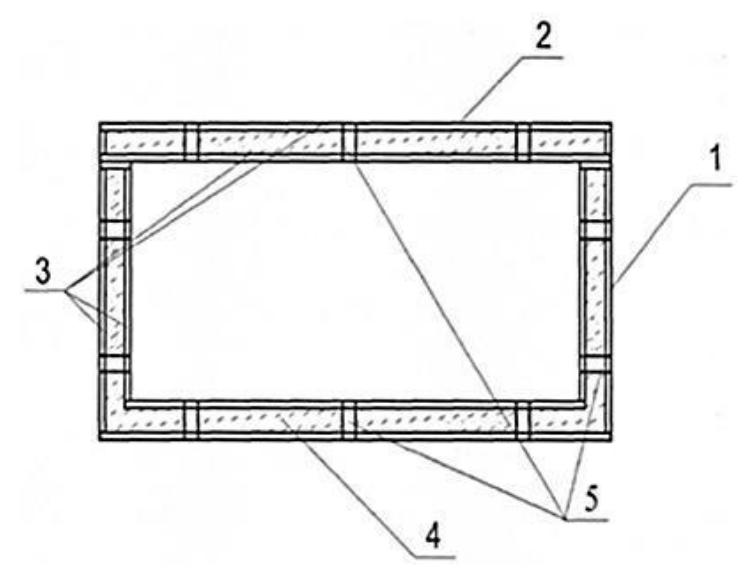

вої інерційності зовнішніх огороджень, які поступово погіршуються в процесі експлуатації традиційних масивних конструкцій, а при використанні «сандвіч»панелей вплив безінерційності набагато більший.

Особливо це важливо для соковитої рослинницької продукції, основний вплив на тривалість зберігання та якість якої має величина амплітуди періодичних коливань температури повітря в камері, що, як зазначено вище, залежить від конструктивних особливостей, умов експлуатації та рівня зносу холодильників. Навіть при підтриманні необхідного середнього рівня параметрів технологічного регламенту, коливання температури у вантажному просторі діючих холодильниківплодоовочесховищ можуть становити $\Delta T_{\text {кам }}=6 \ldots 12^{\circ} \mathrm{C}$ [2].

Існуючі методи, спрямовані на забезпечення стабільності параметрів технологічного регламенту при холодильному зберіганні, засновані на застосуванні огороджувальних конструкцій 3 підвищеною теплостійкістю та модернізованих охолоджуючих систем, не передбачають захист продукту від коливань температури.

Результати багаторічних досліджень, виконані співробітниками IXКЕ ОНАХТ, дозволили вперше зробити висновки про доцільність розробки заходів для збільшення теплової інерційності саме вантажного простору, та його акумулюючої здатності до накопичення холоду [1].

Як засіб підвищення теплової інерційності охолоджуваного простору запропоновано використання для зберігання продукції упаковок з полімерного матеріалу 3 рідинними прошарками [3-7]. Дана упаковка являє собою ящик 3 кришкою, 3 полімерного матеріалу, 3 подвійними стінками. Між зовнішніми та внутрішніми стінками по всьому периметру упаковки утворений зазор, що заповнюється рідиною 3 високою тепловою інерційністю. Як рідину з високою тепловою інерційністю використовують воду або водяні розчини солей, або не замерзаючу воду у капілярних трубках, або багатоатомні спирти, або їх водяні розчини (рисунок 1). 


\section{3. Основна частина}

У Проблемній науково-дослідній лабораторії 3 Холодильної техніки (ПНДЛ ХТ) ОНАХТ проведені дослідження 3 визначення енергетичних витрат при зберіганні продукту (яблук Гала) в упаковках різної конфігурації (з водяними прошарками і без прошарків).

Дослідження проводили в камері холодильника PROFILO, середня температура повітря в якій становила 2,53...2,58 ${ }^{\circ} \mathrm{C}$. Під час кожного 3 дослідів до камери закладали одну упаковку 3 плодами - контрольну або експериментальну. Тривалість проведення одного досліду $-3 \ldots 5$ днів.

При використанні упаковок 3 водяними прошарками заданої товщини (експериментальних, $\delta_{w}=7$ мм, $\delta_{w}=17$ мм і $\delta_{w}=27$ мм) яблука, воду і два контейнери (з оргскла товщиною 3 мм) - зовнішній і внутрішній $(140 \times 140 \times 140$ мм $)$ - охолоджували до $2,4 \ldots 2,6^{\circ} \mathrm{C}$. Розміри зовнішнього контейнера обирали залежно від необхідної товщини водяної прошарку. У простір між контейнерами заливали попередньо охолоджену $\left(2,4 \ldots 2,6{ }^{\circ} \mathrm{C}\right)$ воду, так, щоб внутрішній контейнер 3 яблуками був повністю занурений у воду, і товщина омиваючого шару води була однаковою 3 усіх сторін. Зовнішній контейнер закривали кришкою. Підготовлену упаковку з плодами закладали до камери холодильника.

При використанні упаковки без водяного прошарку (контрольної, $\delta_{w}=0$ мм) яблука і контейнер з кришкою зовнішніми розмірами $140 \times 140 \times 140$ мм охолоджували до температури, близької до середньої температурі в камері $\left(2,4 \ldots 2,6{ }^{\circ} \mathrm{C}\right)$. Потім у контейнер поміщали охолоджені яблука, закривали кришку і закладали упаковку до камери холодильника.

У кришках контейнерів були передбачені отвори для доступу повітря до плодів.

Комплектували вимірювальний вузол: на яблуках, двох протилежних зовнішніх стінках упаковки, та у водяному прошарку (з двох сторін) розміщали термопари. Три термопари вимірювали температуру в камері: на виході і вході до повітроохолоджувача, та у центрі.
Витрати енергії на зберігання визначали за допомогою датчика енергії Lemanso LM669, підключеного до мережі живлення холодильника, який включали відразу після закладання упаковки з яблуками до камери.

\section{1 Витрати енергії при зберіганні}

Всього було проведено 6 дослідів: №№1-3 - при температурі повітря в приміщенні лабораторії $T_{\text {лаб. }}=20 \ldots 21{ }^{\circ} \mathrm{C}$ і №№ $4-6-$ при $T_{\text {лаб. }}=28 \ldots 30^{\circ} \mathrm{C}$.

Результати досліджень показали, що при використанні упаковок з водяними прошарками значно знижуються витрати енергії на зберігання продукту на $17,5 \ldots 21,1 \%$. (таблиця і рисунок 2 ).

Під час проведення дослідів 3 експериментальними упаковками (з водяними прошарками) середня амплітуда коливання температури повітря в камері становила $A_{\text {кам.ср }}=1,87 \ldots 2,11{ }^{\circ} \mathrm{C}$, і була нижчою, ніж при дослідах 3 контрольними $\left(A_{\text {кам.ср }}=2,12 \ldots 2,141{ }^{\circ} \mathrm{C}\right)$ упаковками, а компресор холодильника вмикався i вимикався рідше.

При підвищенні температури повітря в лаборатоpiї від $20 \ldots 21{ }^{\circ} \mathrm{C}$ до $28 \ldots 30^{\circ} \mathrm{C}$ зросли витрати енергії на зберігання 1 кг продукту, однак загальний характер їх зміни залишився незмінним (рисунок 2).

Так, при $T_{\text {лаб. }}=20 \ldots 21^{\circ} \mathrm{C}$ (досліди №№1-3) при використання упаковки з водяним прошарком $\delta_{\mathrm{w}}=7 \mathrm{Mм}$ витрати енергії на на 1 кг продукту знизилися на 18,7\%, а при використанні упаковки з водяним прошарком $\delta_{\mathrm{w}}=$ 17 мм - на 21,1\% (рисунок 2a).

При $T_{\text {лаб. }}=28 \ldots 30{ }^{\circ} \mathrm{C}$ (досліди №№4-6) і використанні упаковки з водяним прошарком $\delta_{\mathrm{w}}=7$ мм енерговитрати на 1 кг продукту були нижче на 17,5\%, а при використанні упаковки з водяною прошарком $\delta_{\mathrm{w}}$ $=27$ мм - нижче на 20,8\% (рисунок 2б).

При цьому збільшення товщини водяного прошарку від 7 мм до 27 мм не призводить до значної економії енергії. Так, різниця між енергетичними витратами при застосуванні упаковок з водяними прошарками 7 мм і 17 мм склала 3\% (досліди №2 і №3); а при застосуванні упаковок з $\delta_{\mathrm{w}}=7$ мм і $\delta_{\mathrm{w}}=27$ мм $-4 \%$ (досліди №5 i №6).

Tаблиця 1 - Енергетичні витрати при використанні упаковок різної конфігурації

\begin{tabular}{|c|c|c|c|c|c|c|}
\hline \multirow[b]{2}{*}{ Назва показника } & \multicolumn{3}{|c|}{$\mathrm{T}_{\text {лаб }}=20 \ldots 21^{\circ} \mathrm{C}$} & \multicolumn{3}{|c|}{$\mathrm{T}_{\text {лаб }}=28 \ldots 30^{\circ} \mathrm{C}$} \\
\hline & $\begin{array}{c}\text { Дослід №1, } \\
\delta_{\mathrm{w}}=0 \mathrm{mм}\end{array}$ & $\begin{array}{c}\text { Дослід №2, } \\
\delta_{\mathrm{w}}=7 \mathrm{Mм}\end{array}$ & $\begin{array}{l}\text { Дослід №3, } \\
\delta_{\mathrm{w}}=17 \mathrm{Mм}\end{array}$ & $\begin{array}{c}\text { Дослід №4, } \\
\delta_{\mathrm{w}}=0 \mathrm{Mм}\end{array}$ & $\begin{array}{c}\text { Дослід №5, } \\
\delta_{\mathrm{w}}=7 \mathrm{мм}\end{array}$ & $\begin{array}{l}\text { Дослід №6, } \\
\delta_{\mathrm{w}}=27 \mathrm{мм}\end{array}$ \\
\hline Тривалість досліду & $\begin{array}{l}92 \text { годин } \\
5 \text { хвилин }\end{array}$ & $\begin{array}{c}38 \text { годин } 27 \\
\text { хвилин }\end{array}$ & $\begin{array}{c}70 \text { годин } 19 \\
\text { хвилин }\end{array}$ & $\begin{array}{c}94 \text { годин } 54 \\
\text { хвилини }\end{array}$ & $\begin{array}{c}95 \text { годин } 26 \\
\text { хвилин }\end{array}$ & $\begin{array}{c}74 \text { годин } 13 \\
\text { хвилин }\end{array}$ \\
\hline Маса яблук в упаковці, кг & 0,896 & 1,099 & 1,188 & 1,211 & 1,1263 & 1,202 \\
\hline $\begin{array}{l}\text { Сумарні витрати енергії на } 1 \\
\text { кг яблук, КВт·год/кг }\end{array}$ & 21,1659 & 7,1834 & 12,739 & 23,6465 & 19,6541 & 14,6475 \\
\hline $\begin{array}{l}\text { Витрати енергії на } 1 \text { кг яблук } \\
\text { за } 1 \text { добу, КВт·год/кг }\end{array}$ & 5,5165 & 4,4838 & 4,348 & 5,9801 & 4,9427 & 4,7367 \\
\hline $\begin{array}{l}\text { Витрати енергії на } 1 \text { кг яблук } \\
\text { за } 60 \text { хвилин, КВт·год/кг }\end{array}$ & 0,2297 & 0,1868 & 0,1812 & 0,2492 & 0,2056 & 0,1974 \\
\hline
\end{tabular}




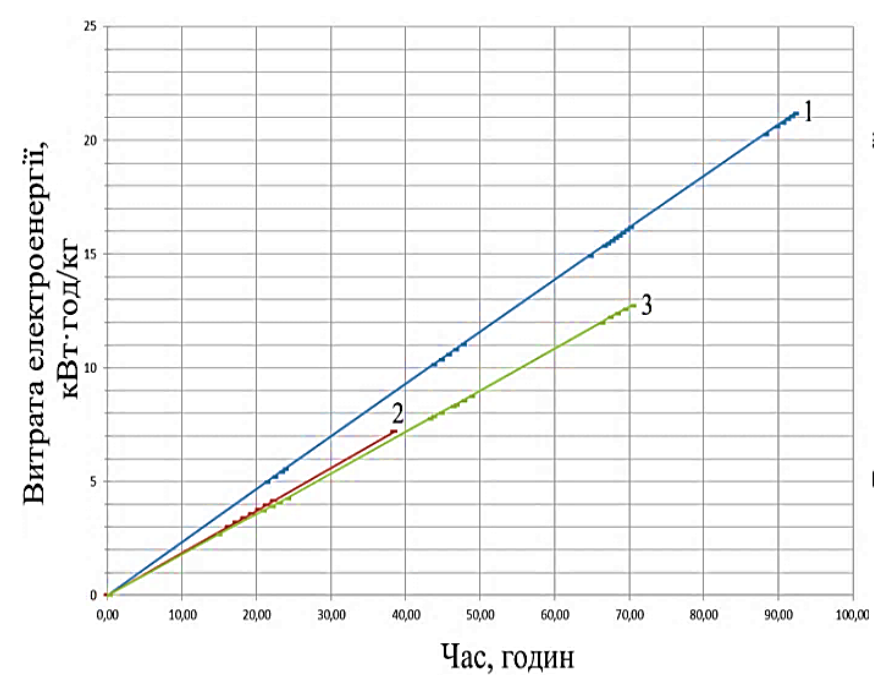

a)

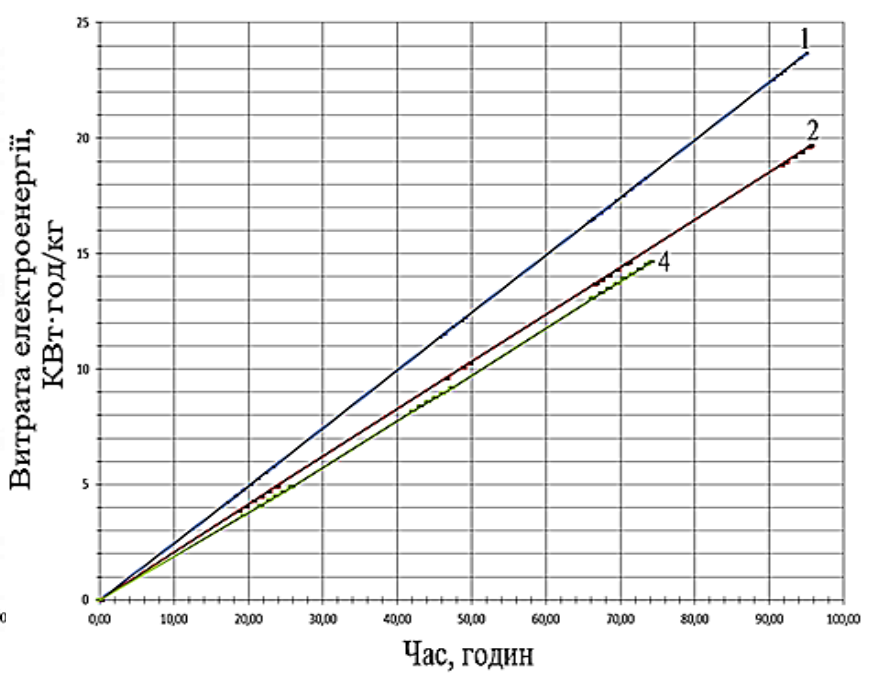

б)

$a-T_{\text {лаб }}=20 \ldots 21{ }^{\circ} \mathrm{C} ; \sigma-T_{\text {лаб }}=28 \ldots 30^{\circ} \mathrm{C} ; 1-$ упаковка без водяного прошарку; 2 - упаковка з водяним прошарком 7 мм; 3 - упаковка з водяним прошарком 17 мм, 4 -упаковка з водяним прошарком 27 мм

Рисунок 2 - Зміна витрат енергії на 1 кг яблук за період зберігання при використанні упаковок різної конфігурації

На рисунку 3 наведені графіки зміни середніх питомих енергетичних витрат на 1 кг за одну годину яблук залежно від конфігурації упаковки.

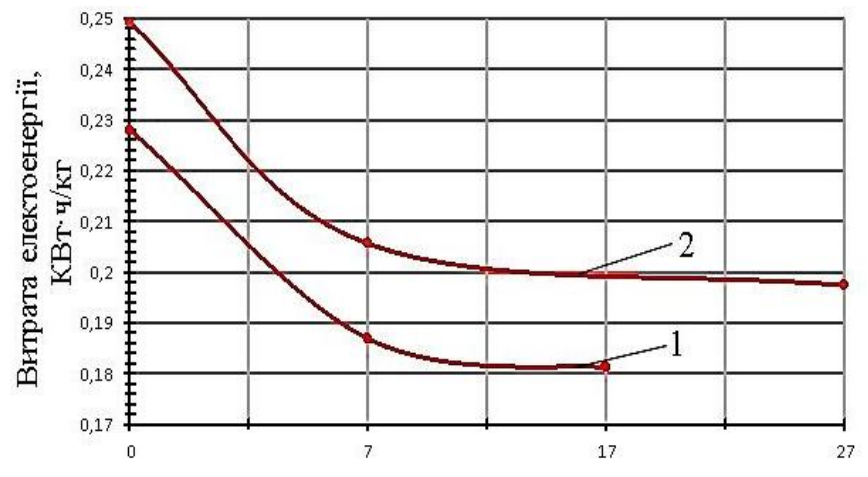

Товщина водяного прошарку, мм

$$
1-T_{\text {лаб }}=20 \ldots 21^{\circ} \mathrm{C} ; 2-T_{\text {лаб }}=28 \ldots 30^{\circ} \mathrm{C}
$$

Рисунок 3 - Средня витрата електроенергії на зберігання 1 кг яблук за 1 годину при застосуванні упаковок з різною товщиною водяних прошарків

3 рисунку 3 також видно, що застосовувати упаковки 3 товщиною водяного прошарку більш, ніж 10 мм, через невелику економію енергії та значне збільшення масогабаритних показників упаковки, що призводить до зниження місткості простору зберігання.

\section{2 Температурні коливання}

Було проведено два досліди 3 контрольною упаковкою (без водяного прошарку): №1 (14.05 - 18.05), при $T_{\text {лаб. }}=20 \ldots 21{ }^{\circ} \mathrm{C}$, загальна тривалість зберігання -3 доби 20 годин 5 хвилин (92 годин 5 хвилин), та №6 (25.06 - 29.06), при $T_{\text {лаб }}=28 \ldots 30^{\circ} \mathrm{C}$, загальна тривалість зберігання - 3 доби 22 години 54 хвилини (94 годин 54 хвилин).
Під час дослідів температура повітря в камері $T_{\text {кам. }}$ змінювалася від $1,27{ }^{\circ} \mathrm{C}$ до $3,78{ }^{\circ} \mathrm{C}$ (при середній $T_{\text {кам.ср. }}=2,528 \ldots 2,58{ }^{\circ} \mathrm{C}$ ), температура зовнішніх стінок упаковки - від 2,26 до $2,89{ }^{\circ} \mathrm{C}$ (при цьому середня $\left.T_{\text {yn.сp. }}=2,523 \ldots 2,569{ }^{\circ} \mathrm{C}\right)$. Температура плодів $T_{\text {пл. зміню- }}$ валась у межах $2,3 \ldots 2,76{ }^{\circ} \mathrm{C}\left(T_{\text {nл.сp. }}=2,489 \ldots 2,546{ }^{\circ} \mathrm{C}\right)$, i середня температура плодів була нижче середньої температури в камері на $0,013 \ldots 0,064^{\circ} \mathrm{C}$.

Середнє змінення температури плодів протягом дослідів $\Delta T_{n л . ~}=0,315 \ldots 328{ }^{\circ} \mathrm{C}$; середня змінення за 1 годину $\Delta T_{\text {пл. }}=0,074 \ldots 0,125^{\circ} \mathrm{C}$.

Амплітуда коливань температури плодов $A_{n л}=$ $0,08 \ldots 0,21{ }^{\circ} \mathrm{C}$, при $A_{\text {пл.ср }}=0,123{ }^{\circ} \mathrm{C}$ (дослід №1) та $A_{\text {пл.сp }}=$ $0,131{ }^{\circ} \mathrm{C}$ (дослід №6); повітря камери $A_{\text {кам. }}=1,9 \ldots 2,35^{\circ} \mathrm{C}$ $\left(A_{\text {кам.ср }}=2,12 \ldots 2,141{ }^{\circ} \mathrm{C}\right), \quad$ стінок упаковки $A_{y n .}=$ $0,12 \ldots 0,4{ }^{\circ} \mathrm{C}\left(A_{\text {yn.cp }}=0,273 \ldots 0,316^{\circ} \mathrm{C}\right)$.

Характер коливань температури повітря камери, зовнішніх стінок упаковки і яблук при зберіганні в упаковці без водяного прошарку показаний на рис. 4 .

3 експериментальними упаковками (3 водяними прошарками заданої товщини) проведено 4 досліди.

3 водяним прошарком товщиною $\delta_{w}=7$ мм: №2 $(22.05-24.05)$, при $T_{\text {лаб. }}=20 \ldots 21{ }^{\circ} \mathrm{C}$, загальна тривалість зберігання - 1 доба 14 годин 27 хвилин (38 годин 27 хвилин), та №5 $(18.06-22.06)$, при $T_{\text {лаб. }}=28 \ldots 30^{\circ} \mathrm{C}$, тривалість зберігання - 3 доби 23 години 26 хвилин (95 годин 26 хвилин).

3 водяним прошарком $\delta_{w}=17$ мм: дослід №3 $(29.05-1.06), T_{\text {лаб. }}=20 \ldots 21^{\circ} \mathrm{C}$, тривалість зберігання 2 доби 22 години 19 хвилин (70 годин 19 хвилин).

3 водяним прошарком $\delta_{w}=27$ мм: № 4 (12.06 $15.06)$, при $T_{\text {лаб. }}=28 \ldots .30{ }^{\circ} \mathrm{C}$, тривалість зберігання -3 доби 2 години 19 хвилин (74 годин 13 хвилин).

Під час дослідів температура повітря в камері $T_{\text {кам. }}$ змінювалася від $1,2{ }^{\circ} \mathrm{C}$ до $3,96{ }^{\circ} \mathrm{C}$ (при $T_{\text {кам.ср. }}=$ $2,53 \ldots 2,56^{\circ} \mathrm{C}$ ), температура зовнішніх стінок упаковки $T_{y n .}-$ від 2,27 до $2,72^{\circ} \mathrm{C}\left(T_{y n . c p .}=2,505 \ldots 2,54{ }^{\circ} \mathrm{C}\right)$.

Температура води в прошарках $T_{w}$ змінювалась від 


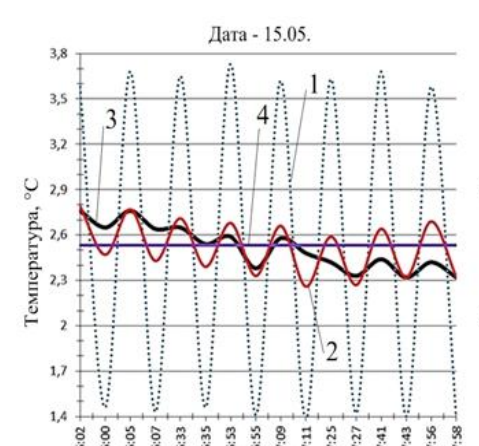

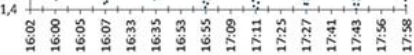
Время, ч

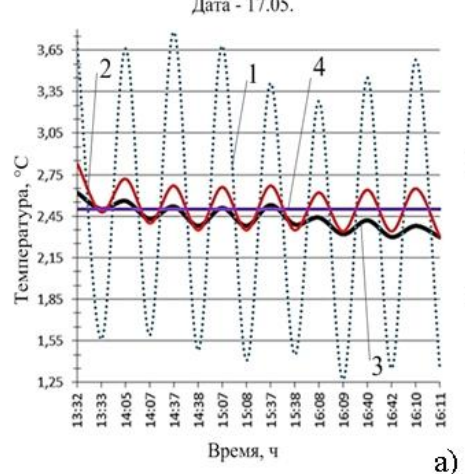

Дата -16.05 .

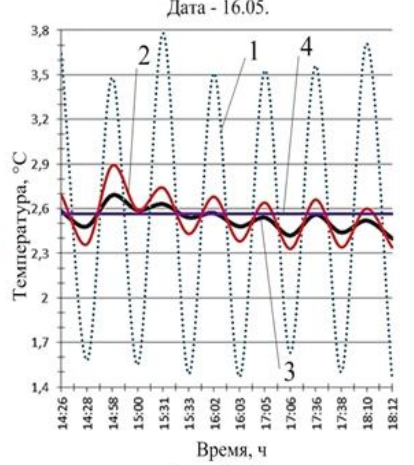$$
\text { 2. }
$$

Дата -18.05

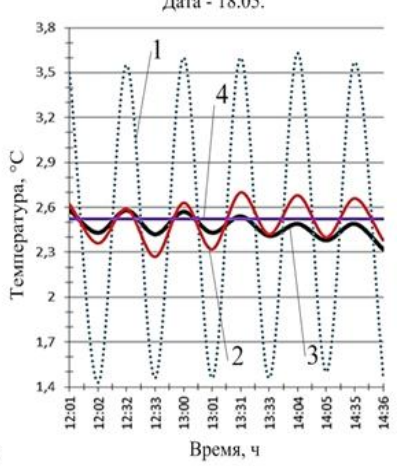

Дата -26.06 .

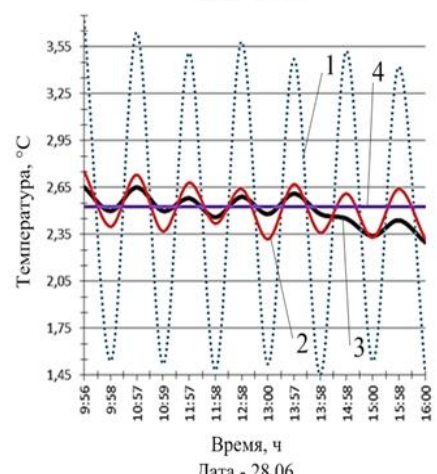

Дата - 28.06

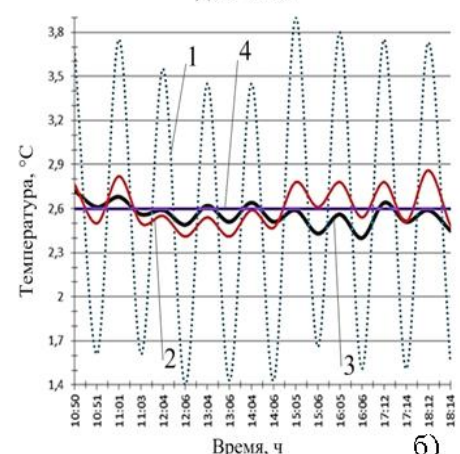

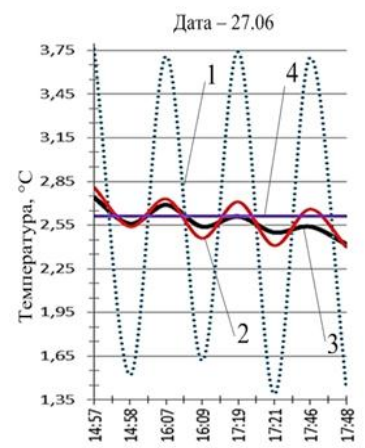

Время, ч Дата - 29.06 .

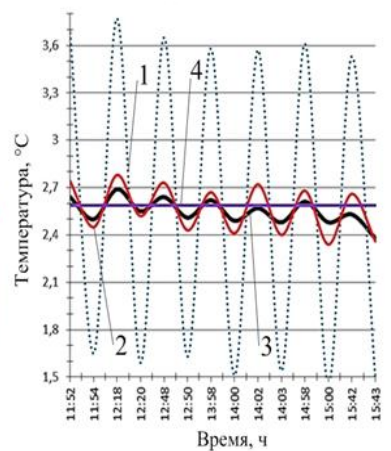

$a-$ дослід №1, $T_{\text {лаб. }}=20 \ldots 21^{\circ} \mathrm{C}, 6-$ дослід №6, $T_{\text {лаб. }}=28 \ldots 30^{\circ} \mathrm{C}$;

1 - температура в камері; 2 - температура зовнішніх стінок упаковки; 3 - температура плодів; 4 - середня температура камери

Рисунок 4 - Змінення температури плодів в упаковщі без водяного прошарку

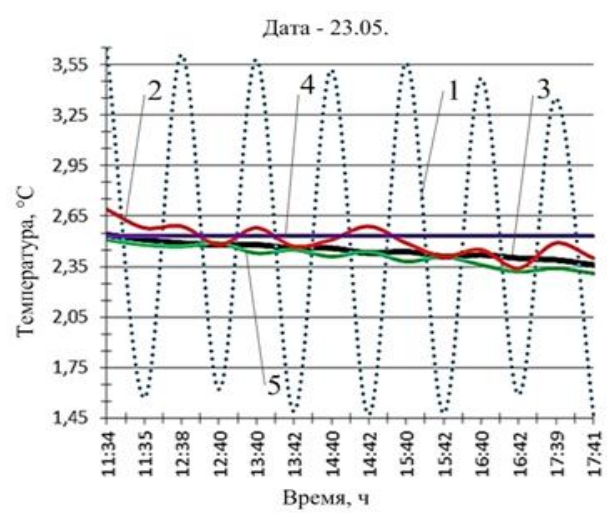

a)

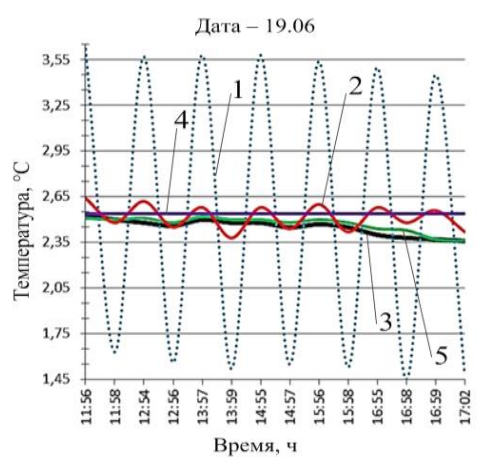

Дата -21.06

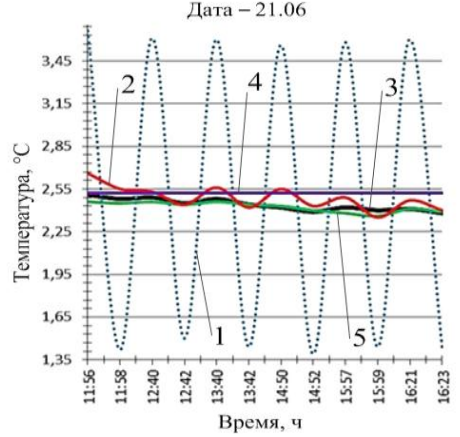

б)

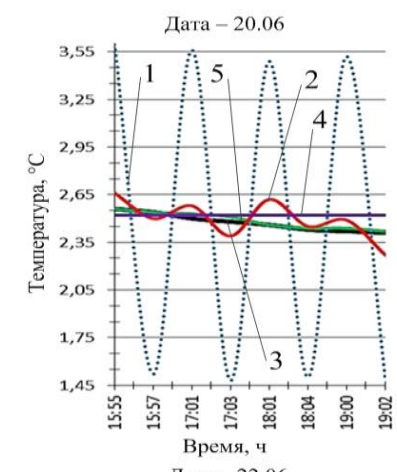

Дата -22.06

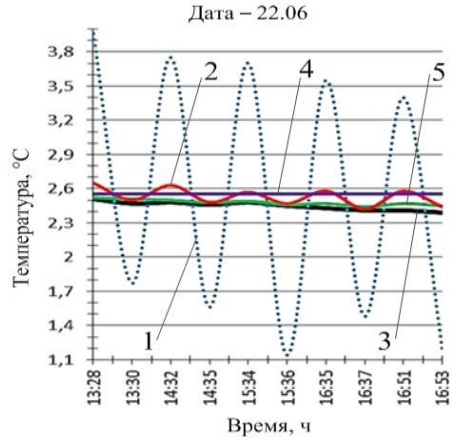

Время, ч

$a-$ дослід №2, $T_{\text {лаб. }}=20 \ldots 21^{\circ} \mathrm{C}, 6-$ дослід №5, $T_{\text {лаб. }}=28 \ldots 30{ }^{\circ} \mathrm{C}$;

1 - температура в камері; 2 - температура зовнішніх стінок упаковки; 3 - температура плодів; 4 - середня температура камери; 5 - температура води в прошарку

Рисунок 5 - Змінення температури плодів в упаковці з водяним прошарком 7 мм 
2,29 до $2,59^{\circ} \mathrm{C}$ (при $T_{\text {w.р. }}=2,414 \ldots 2,488^{\circ} \mathrm{C}$ ), при цьому

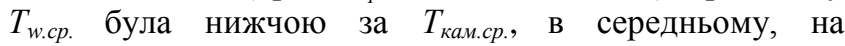
$0,062 \ldots 0,116{ }^{\circ} \mathrm{C}$. Середнє змінення температури води протягом дослідів: $\Delta T_{w}=0,118 \ldots 0,2{ }^{\circ} \mathrm{C}\left(\delta_{w}=7 \mathrm{mм} \mathrm{і} \delta_{w}=\right.$ 17 мм $), \Delta T_{w}=0,08{ }^{\circ} \mathrm{C}\left(\delta_{w}=27 \mathrm{мм}\right)$; середнє змінення за 1 годину $\Delta T_{w .}=0,015 \ldots 0,05^{\circ} \mathrm{C}$.

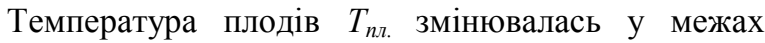
$2,3 \ldots 2,76^{\circ} \mathrm{C}\left(T_{\text {nл.сp. }}=2,489 \ldots 2,546{ }^{\circ} \mathrm{C}\right)$. При цьому $T_{\text {nл.сp. }}$

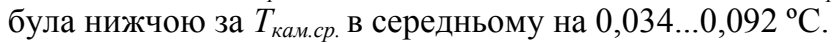

Середнє змінення температури плодів протягом дослідів $\Delta T_{n л .}=0,14 \ldots 0,18{ }^{\circ} \mathrm{C}\left(\delta_{w}=7 \mathrm{i} \delta_{w}=17 \mathrm{Mm}\right), \mathrm{i}$ $\Delta T_{\text {пл. }}=0,117^{\circ} \mathrm{C}\left(\delta_{w}=27 \mathrm{мм}\right)$; середнє змінення за 1 годину $\Delta T_{\text {пл. }}=0,035 \ldots 0,041{ }^{\circ} \mathrm{C}\left(\delta_{w}=7\right.$ мм і $\left.\delta_{w}=17 \mathrm{mм}\right)$, $\Delta T_{\text {пл. }}=0,022{ }^{\circ} \mathrm{C}\left(\delta_{w}=27 \mathrm{MM}\right)$.
Амплітуда коливань температури плодів складала $A_{\text {пл. }}=0 \ldots 0,05{ }^{\circ} \mathrm{C}$, при середніх $A_{\text {пл.сp }}=0,024 \ldots 0,025{ }^{\circ} \mathrm{C}$ $\left(\delta_{w}=7 \mathrm{мm}\right), A_{\text {пл.сp }}=0,016{ }^{\circ} \mathrm{C}\left(\delta_{w}=17 \mathrm{мм}\right)$ i $A_{\text {пл.сp }}=0,013$ ${ }^{\circ} \mathrm{C}\left(\delta_{w}=27\right.$ мм); води $A_{w .}=0 \ldots 0,04{ }^{\circ} \mathrm{C}\left(A_{w . c p}=\right.$ $\left.0,012 \ldots 0,029{ }^{\circ} \mathrm{C}\right)$; повітря камери $A_{\text {кам. }}=1,65 \ldots 2,56{ }^{\circ} \mathrm{C}$ $\left(A_{\text {кам.ср }}=1,871 \ldots 2,11{ }^{\circ} \mathrm{C}\right)$, стінок упаковки $A_{y n}=$ $0,05 \ldots 0,22{ }^{\circ} \mathrm{C}\left(A_{\text {yn.cp }}=0,097 \ldots 0,17^{\circ} \mathrm{C}\right)$.

Характер коливань температури повітря камери, зовнішніх стінок упаковки, води в прошарках і яблук при зберіганні в упаковці з водяним прошарком $\delta_{w}=7$ мм показаний на рисунку 5, в упаковці з водяним прошарком $\delta_{w}=17$ мм - на рисунку 6а, в упаковці з водяним прошарком $\delta_{w}=27$ мм - на рисунку $6 б$.

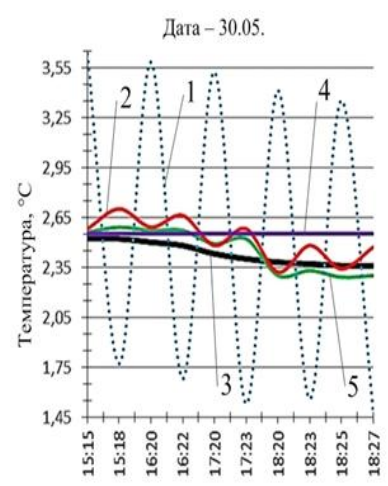

Время, ч

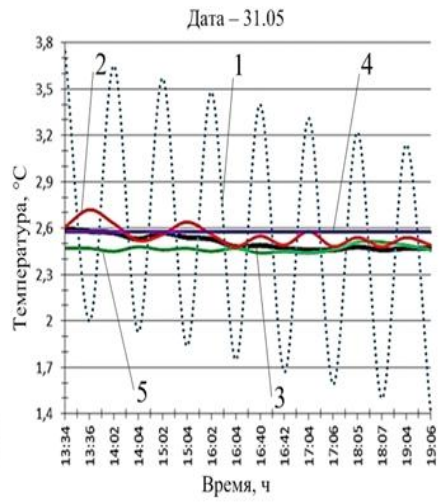

Дата - 01.06 .

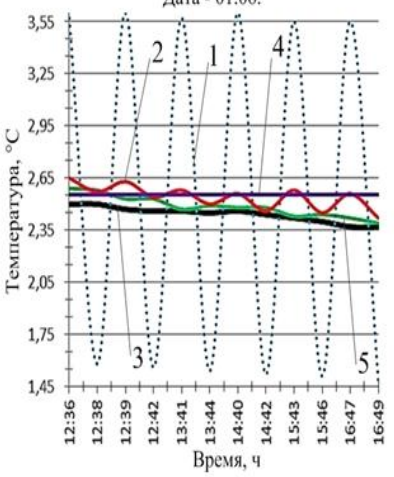

a)
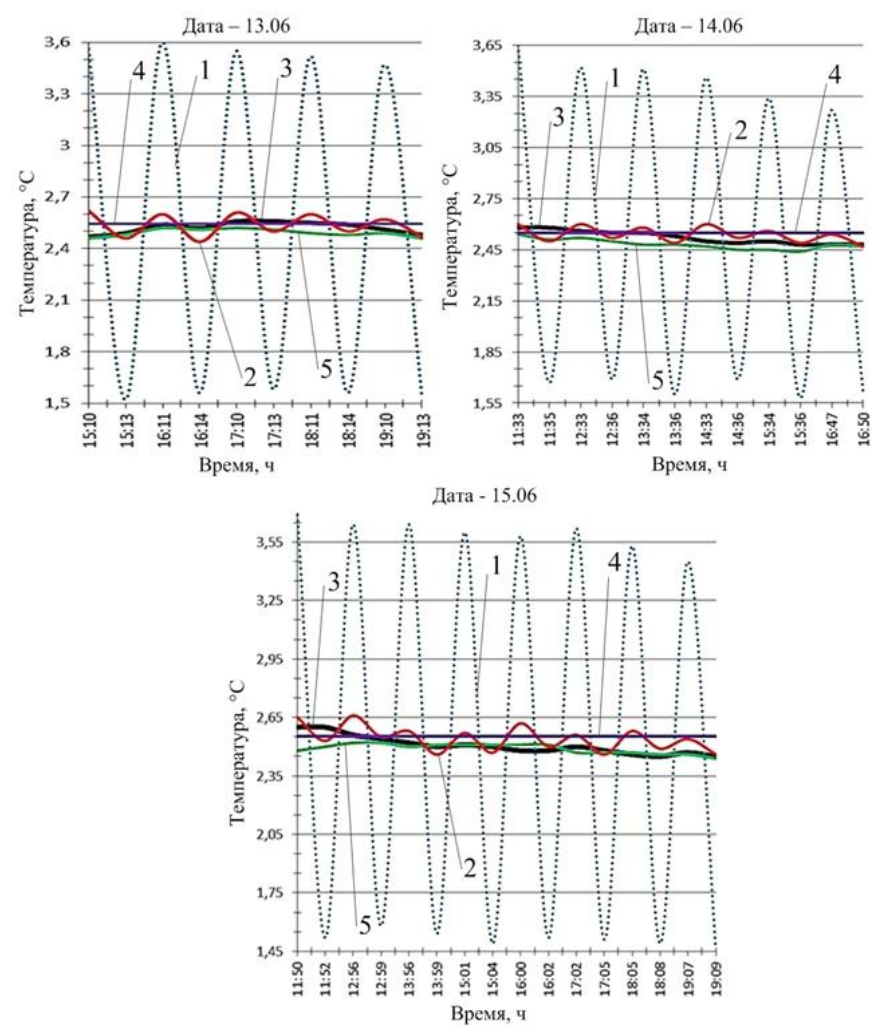

б)

$a-\delta_{w}=17$ мм, дослід №3, $T_{\text {лаб. }}=20 \ldots 21^{\circ} \mathrm{C} ; 6-\delta_{w}=27 \mathrm{Mм}$, дослід №4, $T_{\text {лаб. }}=28 \ldots 30^{\circ} \mathrm{C}$;

1 - температура в камері; 2 - температура зовнішніх стінок упаковки; 3 - температура плодів; 4 - середня температура камери; 5 - температура води в прошарку

Рисунок 6 - Змінення температури плодів в експериментальних упаковках з водяними прошарками

Втрати маси яблук в упаковках з водяними прошарками знизилися на 30,6...38,3\%, у порівнянні з упаковкою без водяного прошарку. Так, втрати маси яблук, що зберігалися в контрольних упаковках, становили 0,0418...0,0436\% за добу, а втрати маси яблук в експериментальних упаковках - 0,0269...0,029\% за добу.

Одержані результати підтвердили дані попередніх досліджень 3 вивчення впливу конструктивних характеристик упаковок різної конфігурації на зміну температури плодів в обсязі упаковки $[2,8,9]$.

Таким чином результати дослідження показали, що в практично рівних умовах зберігання (середня температура в камері і амплітуда іiі коливань) застосування упаковок з підвищеною теплової інерційністю (акуму- лятивною здатністю) 3 водяними прошарками, окрім зниження енергетичних витрат на зберігання (на $17,5 \ldots 21,1 \%)$ :

- призводить до зменшення середнього перепаду температури плодів за 1 годину від $\Delta T_{n л}=0,074 \ldots 0,125{ }^{\circ} \mathrm{C}$ до $\Delta T_{n л}=0,022 \ldots 0,041^{\circ} \mathrm{C}$, що в $1,8 \ldots 3,6$ разів менше, та зменшенню амплітуди коливань температури плодів від $A_{\text {пл.ср. }}=0,123 \ldots 0,131^{\circ} \mathrm{C}$ до $A_{\text {пл.ср. }}=0,013 \ldots 0,025^{\circ} \mathrm{C}$;

- призводить до зменшення амплітуди коливань повітря камери (охолоджуваного простору) (від $A_{\text {кам.ср }}=$ $2,12 \ldots 2,141{ }^{\circ} \mathrm{C}$ до $\left.A_{\text {кам.ср }}=1,87 \ldots 2,11^{\circ} \mathrm{C}\right)-$ за рахунок акумуляції холоду;

- сприяє зниженню втрат маси, більш, ніж на 30\% та збереженню якості плодів за рахунок зменшення коли- 
вань їх температури, та зниження інтенсивності дихання плодів, що призводить до уповільнення дозрівання.

Також зберігання продукту можна здійснювати у стоякових піддонах [10] спеціальної конструкції. Такий піддон містить вантажну платформу, опорний стояковий каркас та знімні елементи з полімерного матеріалу, установлені по периметру та зверху опорного стоякового каркасу, кожен з яких складається з чотирьох бокових, верхньої і нижньої поверхонь, простір між якими заповнений рідиною з високою тепловою інерційністю.

Стояковий піддон використовують у наступному порядку. Тару (з будь-якого придатного для зберігання продукту матеріалу) з попередньо охолодженим продуктом формують у пакети і розміщують на вантажній платформі. Потім в патрубки кутиків каркасу установлюють стояки, які зверху з'єднують між собою. Після цього по периметру і зверху каркасу кріплять знімні елементи, попередньо охолоджені до температури, що відповідає параметрам технологічного регламенту зберігання продукту. Завантажений піддон розміщують у камері, що охолоджується.

\section{4. Висновки}

Запропонований засіб зниження енерговитрат при зберіганні соковитої рослинницької сировини сприятиме зменшенню собівартості зберігання та, відповідно, ціни продукту, продовженню терміну експлуатації холодильного обладнання, а також збереженню якості та подовження строку зберігання продукту. Даний спосіб зберігання може бути застосований у холодильникахплодоовочесховищах будь-якого типу, незалежно від виду будівельно-ізоляційних конструкцій та систем охолодження.

\section{Література}

1. Хмельнюк, М. Г. Важливість стану холодильного господарства у забезпеченні продовольчої безпеки України [Текст]/ М. Г. Хмельнюк, А. Ю. Лагутін, В. П. Кочетов, О. М. Томчик // Наукові праці ОНАХТ.- вип. 45, T. 1. - 2014. - C.116-121.

2. Кочетов, В. П. Упаковки с повышенной тепловой инерционностью для хранения растительной продукции [Текст] / В. П. Кочетов, Е. Н. Томчик // «Пищевая промышленность», Россия. - № 1. - 2014. - С. 16-19. https://elibrary.ru/item.asp?id=21046613
3. Пат. на корисну модель 41517 Україна, МПК В65D 81/24 (2006.01), F 25 D 29/00. Пластикова тара для зберігання плодоовочевої продукції / Томчик О. М. (Україна); власник ОДАХ. - № u200814732, заявл. 22.12.08; опубл. 25.05.2009, бюл. № 10/2009. - 2 с.

4. Пат. на корисну модель 48587 Україна, МПК В65D 81/24 (2006.01), F25D 29/00. Пластикова тара для зберігання плодоовочевої продукції / Томчик О. М. (Україна); власник ОДАХ.- № u200909923, заявл. 29.09.09, опубл. 25.03.2010, бюл. № 6/2010. - 2 с.

5. Пат. на корисну модель №44897 Україна, МПК A01F 25/00, B65D 85/34 (2006.01). Контейнер для зберігання плодоовочевої продукції / Томчик О. М. (Україна); власник ОДАХ. - № u200900999, заявл. 09.02.09; опубл. 26.10.2009, бюл. № 20/2009. - 3 с.

6. Пат. на корисну модель 100447 Україна, МПК А01F 25/14 (2006.01), B65D 85/00, F25D 3/00. Спосіб зберігання сільськогосподарських харчових продуктів або сировини / Томчик О. М., Савін С. М., Кочетов В. П. (Україна); власник ОНАХТ- № u201501050, заявл. 10.02.2015, опубл. 27.07.2015, бюл. № 14/2015. - 5 с.

7. Пат. на корисну модель №118674 Україна, МПК F25D 3/00, B65D 85/00, A01F 25/14 (2006.01). Спосіб зберігання сільськогосподарських харчових продуктів або сировини / Томчик О. М. (Україна); власник ОНАХТ - № u201613596; заявл.29.12.2016; опубл. 28.08.2017, бюл. № 16/2017. - 7 с.

8. Кочетов, В. П. Математическая модель теплообмена в условиях периодических колебаний температуры в камере при использовании упаковок различной конфигурации [Текст] / В. П. Кочетов, Е. Н. Томчик // «Холодильная техника и технология». - № 5 .

- 2013. - C. 64-71. DOI: https://doi.org/10.15673/0453$\underline{8307.5 / 2013.32683}$

9. Кочетов, В. П. Особенности процессов теплообмена между упакованным продуктом и окружающей средой при периодических колебаниях температуры [Текст] / В. П. Кочетов, Е. Н. Томчик // «Пищевая промышленность: наука и технологии» (Беларусь). - № 1 (23). 2014. - C. 50-55.

10. Пат. на корисну модель №100448 Україна, МПК A01F 25/00, B65D 6/10 (2006.01), F25D 1/00, F25D 3/00. Стояковий піддон для сільськогосподарських харчових продуктів або сировини / Томчик О. М., Савін С. М., Кочетов В. П. (Україна); власник ОНАХТ - № u201501051, заявл. 10.02.2015, опубл. 27.07.2015, бюл. № $14 / 2015$. -8 c.

\title{
Reducing of energy spending at work of refrigeration equipment during storage of juicy plant-grower raw materials
}

\author{
O. Tomchyk ${ }^{1 \bowtie}$, M. Khmelniuk ${ }^{2}$, M. Gogol $^{3}$ \\ Odessa National Academy of Food Technologies, 112, Kanatna St, 112, Odessa, 65039, Ukraine \\ $\triangle$ e-mail: Fierysplash@ukr.net \\ ORCID: ${ }^{1}$ https://orcid.org/0000-0002-1132-2481, ${ }^{2}$ https://orcid.org/0000-0002-9310-1286, \\ ${ }^{3}$ https://orcid.org/0000-0003-2679-653X
}

The method of reducing energy costs in refrigerating storage of juicy plant products is considered by increasing the thermal inertia and the accumulation capacity of the cooled space. The means of increasing the thermal inertia of the 
cooled space is the packaging of the original design, made of polymer material, with liquid layers. It is proposed to use a package, which is a box with a lid, with double walls. Between external and internal walls on all perimeter of packing there is the envisaged gap filled by a liquid with a high thermal inertance. A study is undertaken from determination of power charges at storage of product. Results of research on the storage of apple cultivars of Gala (first grade) in packages of different configurations - experimental (with water layers of $7 \mathrm{~mm}, 17$ and $27 \mathrm{~mm}$ ) and control (without layers), showed that at the use of packing with the aquatic layers of expense of energy on storage of product go down on 17,5...21,1\%. Except that, studies have shown that in practically equal conditions of storage (the average temperature in the chamber and the amplitude of its oscillations) at application of packages with increased thermal inertia (accumulation capacity) with water layers, the average temperature drop in the fruit for 1 hour decreased by 1,83,6 times, the amplitude of the temperature fluctuations in the fruits decreased by 4,9..10,1 times, the weight loss of the product decreased by 30,6... 38,3\%, and the amplitude of the air vibrations of the chamber diminished somewhat. Also for storage of product it is possible to apply the pallet of chimney, that contains a freight platform, supporting framework of chimney and removable elements from polymeric material. This removable elements mounted on the perimeter and from above framework. Each removable element consists of four lateral, upper and lower surfaces, the space between which is filled with a liquid with high thermal inertia.

Keywords: Storage of juicy vegetable products is cost of energy Cutting - Fluctuation in a temperature-Accumulation of cold - Packaging with high thermal inertia.

\section{References}

1. Khmelniuk M., Lagutin A., Kochetov V., Tomchyk O. (2014). Vajlyvist stanu kholodylnogo gospodarstva u zabezpechenni prodovolchoi bezpeky Ukrainy. Naukovi pratsi ONAHT, Vyp. 45, T. 1, P. 116-121.

2. Kochetov, V., Tomchyk, E. (2014) Upakovki s povyishennoy teplovoy inertsionnostyu dlia hraneniia rastitelnoy produktsii.Pischevaya promyshlennost (Russia), №1, P. 16-19. https://elibrary.ru/item.asp?id=21046613

3. Pat. 41517 Ukraina, B65D 81/24 (2006.01), F25D 29/00. Plastikova tara dlia zberigannia plodoovochevoi produktcii/Tomchyk O. M. (Ukraina) - № u200814732; zaiavl. 22.12.08; opubl. 25.05.2009, biul. №10/2009. - 2 s.

4. Pat. 48587 Ukraina, B65D 81/24 (2006.01), F25D 29/00. Plastirova tara dlia zberihannia plodoovochevoi produktcii / Tomchyk O. M. (Ukraina) - № u200909923; zaiavl. 29.09.09; opubl. 25.03.2010, biul. №6/2010. - 2 s.

5. Pat. 44897 Ukraina, A01F 25/00, B65D 85/34 (2006.01). Konteiner dlia zberihannia plodoovochevoi produktsii / Tomchyk O. M. (Ukraina) - № u200900999, zaiavl. 09.02.09; opubl. 26.10.2009, biul. №20/2009. - 3 s.

6. Pat. 100447 Ukraina, A01F 25/14 (2006.01), B65D 85/00, F25D 3/00. Sposib zberihannia silskohospodarskykh kharchovykh produktiv abo syrovyny / Tomchyk O. M., Savin S. M., Kochetov V. P. (Ukraina) - №u201501050; zaiavl. 10.02.2015; opubl. 27.07.2015, biul. №14/2015. 5 s.
7. Pat. 118674 Ukraina, F25D 3/00, B65D 85/00, A01F 25/14 (2006.01). Sposib zberihannia silskohospodarskykh kharchovykh produktiv abo syrovyny / Tomchyk O. M. (Ukraina) - № u201613596; zaiavl. 29.12.2016; opubl. 28.08.2017, biul. № 16/2017. - 7 s.

8. Kochetov, V., Tomchyk E. (2013) Matematycheskaia model teploobmena $\mathrm{v}$ usloviiakh periodicheskikh kolebanii temperatury v kamere pri ispolzovanii upakovok razlichnoi konfyhuratsii. Holodilnaia tehnika i tehnolohiia, №5, P. 6471. DOI: https://doi.org/10.15673/0453-8307. 5/ 2013. 32683

9. Kochetov, V., Tomchyk E. (2014) Osobennosti protsessov teploobmena mezhdu upakovannym produktom i okruzhaiushchei sredoi pri periodicheskikh kolebaniiakh temperatury/ Pishchevaia promyshlennost: nauka i tekhnolohii» (Belarus), №1 (23), P. 50-55.

10. Pat. 100448 Ukraina, $A 01 F$ 25/00, B65D 6/10 (2006.01), F25D 1/00, F25D 3/00. Stoiakovyi piddon dlia silskohospodarskykh kharchovykh produktiv abo syrovyny / Tomchyk O. M., Savin S. M., Kochetov V. P. (Ukraina).№u201501051, zaiavl. 10.02.2015, opubl. 27.07.2015, biul. №14/2015. -8 s. 